\title{
Asymptomatic Carriage of C. botulinum Type D/C in Broiler Flocks as the Source of Contamination of a Massive Botulism Outbreak on a Dairy Cattle Farm
}

\begin{abstract}
Rozenn Souillard ${ }^{1}$, Daniel Grosjean ${ }^{2}$, Thibault Le Gratiet ${ }^{3}$, Typhaine Poezevara ${ }^{3}$, Sandra Rouxe/ ${ }^{3}$, Loïc Balaine ${ }^{1}$, Sabrina Macé ${ }^{3}$, Laure Martin ${ }^{3}$, Fabrizio Anniballi ${ }^{4}$, Marianne Chemaly ${ }^{3}$, Sophie Le Bouquin ${ }^{1}$ and Caroline Le Marécha/ ${ }^{3 *}$
\end{abstract}

\begin{abstract}
'ANSES, French Agency for Food, Environmental and Occupational Health Safety, Epidemiology, Health and Welfare Unit, Ploufragan, France, ${ }^{2}$ DDCSPP de la Meuse, Departmental Authority in Charge of Veterinary Services for Meuse Department, Bar-le-Duc, France, ${ }^{3}$ ANSES, French Agency for Food, Environmental and Occupational Health Safety, Hygiene and Quality of Poultry and Pig Products Unit, Ploufragan, France, ${ }^{4}$ Department of Veterinary Public Health and Food Safety, National Reference Centre for Botulism, Istituto Superiore di Sanità, Rome, Italy
\end{abstract}

OPEN ACCESS

Edited by:

Javier Carballo,

University of Vigo, Spain

Reviewed by:

Krzysztof Skowron

Nicolaus Copernicus University

in Toruń, Poland

Frederique Pasquali,

University of Bologna, Italy

*Correspondence:

Caroline Le Maréchal

caroline.lemarecha/@anses.fr

Specialty section:

This article was submitted to

Food Microbiology,

a section of the journal

Frontiers in Microbiology

Received: 11 March 2021

Accepted: 07 June 2021

Published: 29 June 2021

Citation:

Souillard R, Grosjean D,

Le Gratiet T, Poezevara T, Rouxel S,

Balaine L, Macé S, Martin L,

Anniballi F, Chemaly M, Le Bouquin S

and Le Maréchal C (2021)

Asymptomatic Carriage of

C. botulinum Type D/C in Broiler

Flocks as the Source

of Contamination of a Massive

Botulism Outbreak on a Dairy Cattle

Farm. Front. Microbiol. 12:679377.

doi: 10.3389/fmicb.2021.679377
In winter 2018, a massive type D/C cattle botulism outbreak occurred on a mixed dairy and broiler farm in France. An investigation was conducted based on the hypothesis of asymptomatic carriage in poultry. We set out to identify the source of contamination of the dairy cattle and to monitor the contamination of broilers over time, including the hatchery delivering chicks to the farm. Environmental samples were collected on the farm during the cattle outbreak ( $n=40$ ), after the outbreak for three successive broiler flocks $(n=128)$, and once in the hatchery delivering the chicks $(n=58)$. These samples were analyzed using real-time PCR after an enrichment step to detect Clostridium botulinum type $\mathrm{D} / \mathrm{C}$. The results showed contamination in the manure from the broilers raised just before the onset of the cattle outbreak $(5+/ 5)$, as well as in some of the components of the cattle ration $(3+/ 17)$. This latter contamination is likely due to the use of the same tractor bucket to remove litter from the poultry house and to prepare the cattle ration on the same day. Contamination monitoring over several months revealed continuous asymptomatic carriage in the broilers $(4+/ 20$ and $17+/ 20$ cloacal swabs in 2 successive flocks), a persistence of $C$. botulinum type D/C in the ventilation system of the poultry house $(8+/ 14)$, and contamination of the equipment coming from the hatchery used for delivering the chicks $(3+/ 18)$. Further investigations conducted in the hatchery demonstrated contamination in the hatchery by $\mathrm{C}$. botulinum type D/C $(6+158)$. Comparison of samples using a multilocus variable number tandem repeat analysis showed the same profile for samples collected on broilers, cattle and in the hatchery. This study highlighted the crucial role of the implementation of biosecurity measures in mixed farms to avoid cross-contamination between production units given the potential asymptomatic carriage of poultry. This study also revealed the contamination of the poultry hatchery. Further investigations are required to better understand the role of hatcheries in the epidemiology of animal botulism.

\footnotetext{
Keywords: botulism, cattle, poultry, epidemiology, hatchery, investigation, MLVA, PCR
} 


\section{INTRODUCTION}

Botulism is a severe neurological disease caused by botulinum neurotoxins (BoNT) that prevent the release of acetylcholine at synaptic junctions and result in progressive symmetrical flaccid paralysis of muscles. There are nine different BoNTs (A, $\mathrm{B}, \mathrm{C}, \mathrm{D}, \mathrm{E}, \mathrm{F}, \mathrm{G}, \mathrm{H}$, or H/A, or F/A, X) (Rasetti-Escargueil et al., 2020) and more than 40 subtypes have been described (Peck et al., 2017). Human botulism is a rare disease is mainly caused by BoNTs A, B, E, and to a lesser extent, F (RasettiEscargueil et al., 2019). Botulism is more common in animals than in humans and results in high mortality rate, raising significant animal welfare and economic concerns (Anniballi et al., 2013; Relun et al., 2017; Rasetti-Escargueil et al., 2019). Avian botulism is generally associated with BoNT C/D, whereas bovine botulism is more frequently associated with BoNT D/C, and to a lesser extent, BoNT C (Woudstra et al., 2012; Bano et al., 2017; Le Gratiet et al., 2020). Considering the serious consequences of botulism on bovine and avian species, a better understanding of this disease - particularly in terms of potential mechanisms of transmission - is crucial to improve prevention and management of animal botulism outbreaks in an efficient manner.

Poultry litter has been considered as a major source of contamination for cattle botulism outbreaks via contact or close proximity (Popoff, 1989; Payne et al., 2011; Relun et al., 2017). Cross-contamination from poultry to cattle has been widely reported in the literature (Senturk and Cihan, 2007; Payne et al., 2011; Ramírez-Romero et al., 2014; Relun et al., 2017; Souillard et al., 2017). Poultry is indeed considered as a reservoir and source of amplification of type D Clostridium botulinum and its toxin (Popoff and Argente, 1996). Poultry litter can be used as fertilizer, animal bedding or even as feed supplements (Payne et al., 2011). Surprisingly, no data is available on the prevalence of C. botulinum or BoNTs in poultry litter or more generally in healthy poultry. Recently, healthy carriage on a poultry farm was suspected as a source of two cattle botulism outbreaks due to a transfer of poultry manure to the cattle farms (Souillard et al., 2017). Consequently, asymptomatic carriage of $C$. botulinum in poultry can occur, which may represent a reservoir of C. botulinum (Rasetti-Escargueil et al., 2019). Animals are either resistant to some BoNT types or C. botulinum carriage occurs at low bacterial loads in the digestive tract (Rasetti-Escargueil et al., 2019). These low levels may explain the failure to detect C. botulinum carriage in previous studies, as they may be below the limit of detection of available methods (Popoff, 1989).

In 2018, a large BoNT type D/C cattle botulism outbreak occurred on a farm with both dairy and broiler production units in eastern France. Based on the hypothesis of asymptomatic C. botulinum carriage in poultry, the objectives of this study were (i) to identify the source of cattle botulism contamination using epidemiological investigations and strain tracking and (ii) to monitor the contamination of broilers over time including at the hatchery delivering chicks to the farm.

\section{MATERIALS AND METHODS}

\section{Case History and Diagnosis of Botulism on the Farm}

A botulism outbreak occurred in winter 2018 on a farm with dairy and broiler production in Meuse department, located in eastern France. Figure 1 shows the different barns of the farm. Ninetytwo dairy cows were being housed in Barn B and 25 heifers, calves and dry cows in Barn C. These two barns are separated by about $20 \mathrm{~m}$. During winter, cattle are kept indoors and, beginning early spring, grazed on pasture. The Barn A poultry house is separated by about $10 \mathrm{~m}$ from Barn B. It is a "Louisiane"-style barn of $1000 \mathrm{~m}^{2}$ with windows, natural and transversal ventilation, and a dirt floor. In this house, a flock of 20000 broilers (Flock No. 1) was reared in January 2018. Moreover, the farm has two sheds: Shed A for the storage of the cattle ration ingredients and Shed B for straw storage. In addition, corn silage is also stored on a platform near Shed B. A second site for cattle production is located about $10 \mathrm{~km}$ away from this area.

On January 29, the first clinical signs of paralysis were observed in dairy cows in Barn B and mortality started (Table 1). On 30 January, samples were collected on two cows that died after showing clinical signs suggestive of botulism. The liver, gall bladder, rectal contents, ruminal contents, feces, and intestines were frozen before shipment to the laboratory. C. botulinum types $\mathrm{C}, \mathrm{D}, \mathrm{C} / \mathrm{D}$, and $\mathrm{D} / \mathrm{C}$ in these samples were screened for as previously described (Le Maréchal et al., 2019). Ruminal contents from the two investigated cows as well as rectal contents from one cow were positive for C. botulinum type D/C using realtime PCR after enrichment in trypticase peptone-glucose-yeast extract (TPGY) broth. None of the samples were positive when using fortified-cooked meat medium (F-CMM) with a thermal treatment $\left(70^{\circ} \mathrm{C}, 10 \mathrm{~min}\right)$. On 31 January, signs of paralysis and mortality also occurred in the heifers in Barn C. No clinical signs and no mortality were observed on the second site $10 \mathrm{~km}$ away. Vaccination using Ultravac ${ }^{\circledR}$ Botulinum (Zoetis, France) was performed on February 2 with a second injection on March 5 in both cattle barns.

Two phases of death were observed on the farm. Mortality was high within the first week (January 29 to February 5) with 68 dead cows in Barn B and 8 heifers in Barn C. A second mortality phase was observed from February 26 to March 5 with 15 cows and 1 heifer. Out of the 117 cows present on the farm at the beginning of the outbreak, 92 cows died, indicating a mortality rate of $79 \%$. All animals with clinical signs eventually died (naturally or humanely euthanized), no recovery was reported.

\section{Epidemiological Investigation and Collection of Environmental Samples on the Farm}

An epidemiological investigation was conducted on the farm. A questionnaire was filled out with the farmer and the veterinarian to describe the history and chronology of the cases. It included questions on the overall management of cattle and poultry (farming practices and manure management, etc.) and 


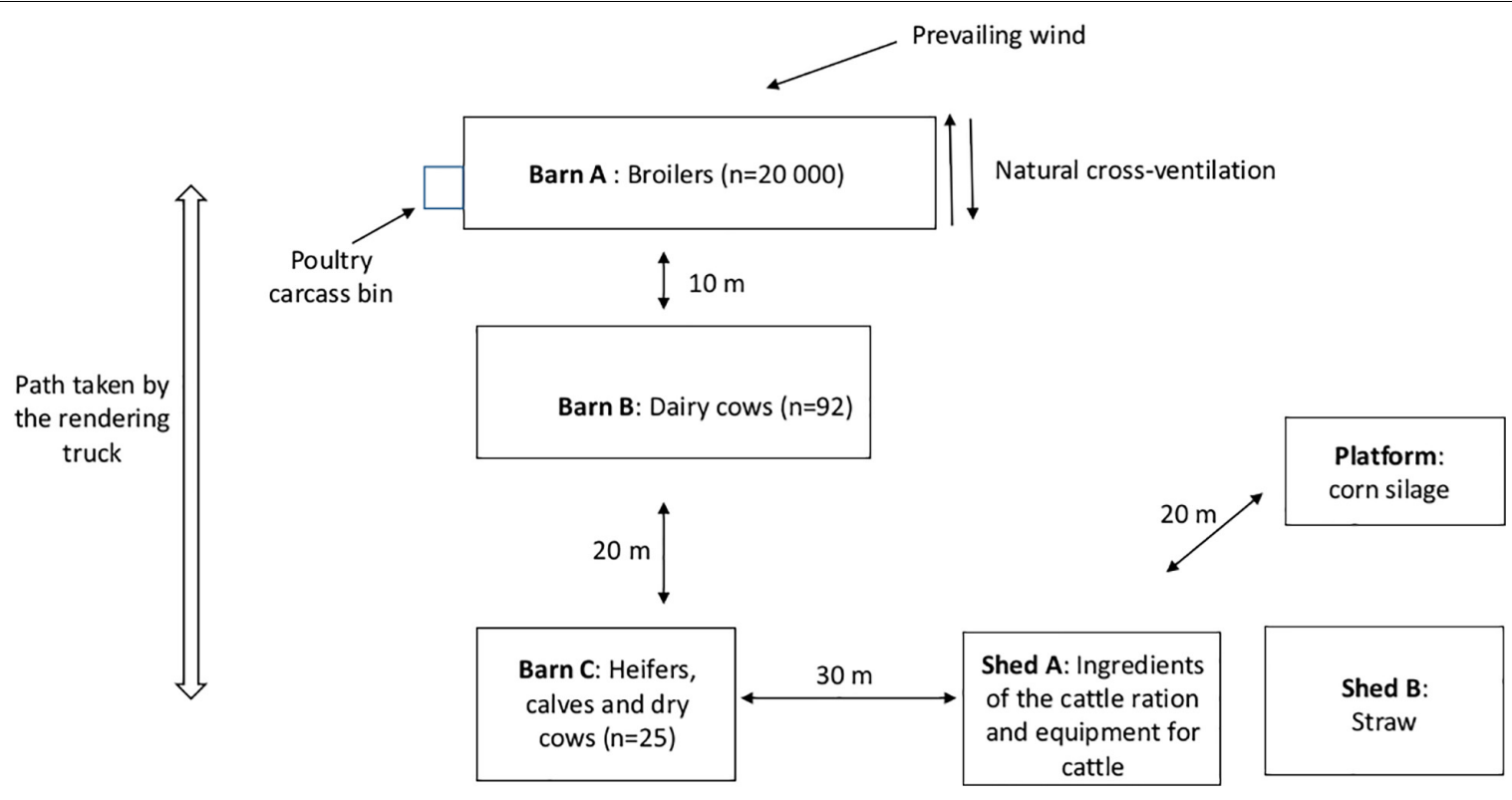

FIGURE 1 | Layout of the mixed farm site that experienced a type D/C botulism outbreak in Eastern France in winter 2018.

the movements of material, personnel, and vehicles between the poultry and dairy production areas.

During the outbreak, environmental samples $(n=40)$ were collected on the farm on three different days (January 30, February 5, and February 23) to investigate the source of contamination of the cattle (Table 1): 17 samples of the cattle ration stored in Shed $\mathrm{A}(n=14)$ and on the platform $(n=3), 5$ samples of the broiler manure from Flock No. 1 stored in a field since January 26, 3 samples in Barn B, 5 samples in Shed A and 10 samples in Barn A and its surroundings.

After the end of the outbreak, samples $(n=128)$ were also collected for several months in the poultry house to monitor the contamination of broilers over time (Table 2): 9 swabs after cleaning and disinfecting the house with 7 swabs inside the house and 2 swabs outside the house; 55 swabs on the day of chick delivery to the farm, including 11 swabs inside the house; 2 swabs outside the house, 20 cloacal swabs on chicks, 18 swabs on hatchery-origin material, and 4 swabs on the material returned to the hatchery; and finally 64 swabs at the end of the rearing period, with 4 swabs inside the poultry house and 60 cloacal swabs of broilers on the three following broiler flocks (Flocks No. 3, 4, and 5). It was not possible to sample the second flock of broilers reared just after Flock No. 1. Swabs used for sample collection in the farm were obtained from Sodibox (Nevez, France). Cloacal swabs were collected by veterinarians in accordance with the European and French regulation on farmed animal protection.

\section{Epidemiological Investigation and Collection of Environmental Samples in the Hatchery}

An epidemiological investigation was also conducted at the hatchery providing the chicks. A questionnaire was filled out with the hatchery owner to collect information on the hatchery operations (from egg hatching to the departure of chicks, cleaning and disinfection, waste management, and vehicle movements on the site, biosecurity measures, etc.). A breeder house was also located on a site near the hatchery. At the hatchery site, samples $(n=58)$ were collected (swabs taken on the walls, floor and equipment): 41 inside the hatchery (egg receiving room, incubation and hatcher rooms, chick sorting, and departure rooms), 9 outside the hatchery (truck platform, waste containers, central area and breeder house surroundings) and 8 in annex rooms (trolley storage rooms and refrigerated egg holding rooms).

\section{Culture Conditions, DNA Extraction, and Real-Time PCR}

Enrichment of 226 samples, DNA extraction and PCR were performed as previously described (Le Maréchal et al., 2019).

\section{Multilocus Variable-Number of Tandem-Repeat Analysis (MLVA)}

Thirteen DNA extracts positive for type D/C (with a Ct below 35) were selected for MLVA analysis using nine conventional PCRs (Supplementary Table 1), one for each variable number tandem repeat (VNTR) locus as described previously in Auricchio et al. (2019) and Scalfaro et al. (in preparation) ${ }^{1}$. The MLVA PCR mixture contained $10 \mu \mathrm{L}$ of HotStarTaq Master mix (Qiagen, Courtaboeuf, France), $1 \mu \mathrm{L}$ of forward and reverse primers (10 $\mu \mathrm{M}$ for a final concentration of $500 \mathrm{nM}$ ), $7 \mu \mathrm{L}$ of water and $1 \mu \mathrm{L}$ of template DNA. Amplification consisted of the following

\footnotetext{
${ }^{1}$ Scalfaro, C., Vicenza, T., Le Maréchal, C., Bano, L., Bilei, S., Chemaly, M., et al. (in preparation). Multilocus variable-number of tandem-repeat analysis as a tool for Clostridium botulinum group III sub-typing. Microorganisms
} 
TABLE 1 | Chronology of the events on the farm affected by the cattle botulism outbreak type $D / C$ and detection of $C$. botulinum type D/C during the outbreak.

\begin{tabular}{|c|c|c|c|c|c|c|c|c|c|c|}
\hline & $22 / 01 / 18$ & $26 / 01 / 18$ & $27-28 / 01 / 18$ & $29 / 01 / 18$ & $30 / 01 / 18$ & $31 / 01 / 18$ & $02 / 02 / 18$ & $05 / 02 / 18$ & $23 / 02 / 18$ & 05/03/18 \\
\hline $\begin{array}{l}\text { Chronology of } \\
\text { the outbreak } \\
\text { events }\end{array}$ & $\begin{array}{l}\text { Departure } \\
\text { of broilers } \\
\text { (Flock No } 1 \\
\text { Barn A) for } \\
\text { slaughter }\end{array}$ & $\begin{array}{l}\text { Removal of broiler litter } \\
\text { using a tractor bucket } \\
\text { and storage of manure } \\
\text { in a field } \\
\text { Transfer of the } \\
\text { ingredients of the cattle } \\
\text { ration (Shed A) with the } \\
\text { same bucket in a } \\
\text { mixing wagon to feed } \\
\text { cows. }\end{array}$ & $\begin{array}{l}\text { Heifers fed with } \\
\text { leftovers from } \\
\text { the cattle ration } \\
\text { Cleaning and } \\
\text { disinfection of } \\
\text { the broiler } \\
\text { house (Barn A) }\end{array}$ & $\begin{array}{l}\text { Detection } \\
\text { of paralysis } \\
\text { and first } \\
\text { cow } \\
\text { mortalities } \\
\text { (Barn B) }\end{array}$ & $\begin{array}{l}\text { Diagnosis of } \\
\text { botulism: } \\
\text { C. botulinum type } \\
\text { D/C in } \\
\text { ruminal contents } \\
\text { (S3) }(2+/ 2)^{*} \text { and } \\
\text { rectal content } \\
(1+/ 2)^{\star}\end{array}$ & $\begin{array}{l}\text { Paralysis } \\
\text { and heifer } \\
\text { mortalities } \\
\text { (Barn C) }\end{array}$ & $\begin{array}{l}\text { Vaccination } \\
\text { of all } \\
\text { animals } \\
\text { (including } \\
\text { calves, dry } \\
\text { cows) with } \\
\text { Utravac } \\
\text { Botulinum } \\
\text { (first } \\
\text { injection) }\end{array}$ & & & $\begin{array}{l}\text { Vaccination } \\
\text { with } \\
\text { Ultravac } \\
\text { Botulinum } \\
\text { (second } \\
\text { injection) }\end{array}$ \\
\hline $\begin{array}{l}\text { Detection of } \\
\text { C. botulinum } \\
\text { type } D / \text { Con the } \\
\text { farm }^{*}(n=40)\end{array}$ & & & & & $\begin{array}{l}\text { Cattle ration } \\
\text { Shed A }(n=3) \\
\text { Wrapped grass } \\
1+/ 3\end{array}$ & & & $\begin{array}{l}\text { Cattle ration } \\
\text { Shed A } \\
(n=11) \\
\text { Meslin }(S 1) \\
\mathbf{1 + / 3} \\
\text { Rape } 1+/ 3 \\
\text { Brewery grains } \\
0+/ 3 \\
\text { Corn } 0+/ 2 \\
\text { Cattle ration } \\
\text { Platform } \\
(n=3) \\
\text { Corn silage } \\
0+/ 3 \\
\text { Broiler } \\
\text { manure } \\
\text { stored since } \\
\mathbf{2 6 / 0 1 ~}(n=5) \\
\text { Manure }(S 2) \text { in } \\
\text { a field } 5+/ 5\end{array}$ & $\begin{array}{l}\text { Barn } \mathbf{B}-(\boldsymbol{n}=\mathbf{3}) \\
\text { Liquid manure } \mathbf{1}+/ \mathbf{1} \\
\text { Swab of the floor of the } \\
\text { stall } \mathbf{1}+/ \mathbf{1} \\
\text { Swab of cattle feed } \\
\text { table } 0+/ 1 \\
\text { Shed } \mathbf{A}(\boldsymbol{n}=\mathbf{5}) \\
\text { Swab of the floor of the } \\
\text { shed } 0+/ 1 \\
\text { Swab of the bucket } \\
\mathbf{1}+/ \mathbf{1} \\
\text { Swab of the tarpaulin } \\
\text { covering rape } \mathbf{1}+/ \mathbf{1} \\
\text { Swab of the rape } \\
\text { storage area } 0+/ 1 \\
\text { Swab in the mixing } \\
\text { wagon } \mathbf{1}+/ \mathbf{1} \\
\text { Barn } \mathbf{A} \text { ( } \mathbf{n}=\mathbf{1 0 )} \\
\text { Inside the house } \\
\text { Swab of the ventilation sys } \\
\mathbf{2}+/ \mathbf{4} \\
\text { Swab of the floor of the } \\
\text { house } 0+/ 1 \\
\text { Swab of the shower? } \\
\text { room } 0+/ 1 \\
\text { Feed from silo } 0+/ 1 \\
\text { Outside the house } \\
\text { Swab of the } \\
\text { surroundings } 0+/ 1 \\
\text { Swab of the carcass bin } \\
\mathbf{1}+/ \mathbf{1} \\
\text { Swab of the path } 0+/ 1\end{array}$ & \\
\hline
\end{tabular}

*Number of positive samples/number of samples collected.

Samples tested by MLVA are underlined and the sample code in Figure 2 is indicated in parentheses. Samples detected positive are in bold. 
TABLE 2 | Detection of C. botulinum type D/C in the poultry house after the cattle outbreak $(n=128)$ using swab samples.

\begin{tabular}{|c|c|c|c|c|c|c|c|c|c|}
\hline \multirow{3}{*}{ Flock No $1^{\star}$} & \multicolumn{3}{|c|}{$\begin{array}{l}\text { After extensive disinfection } \\
\text { of the poultry house } n=9\end{array}$} & \multicolumn{3}{|c|}{ Upon chick delivery $n=55$} & \multicolumn{3}{|c|}{ Upon broiler departure $n=64$} \\
\hline & \multirow[t]{2}{*}{$21 / 03 / 18$} & $\begin{array}{l}\text { Inside the } \\
\text { house } n=7\end{array}$ & $\begin{array}{l}\text { Ventilation system } \\
\text { (S5) } 2+/ \mathbf{4} \\
\text { Floor of the house } \\
0+/ 1 \\
\text { Changing room } \\
0+/ 1 \\
\text { Feed silo } 0+/ 1\end{array}$ & & & & & & \\
\hline & & $\begin{array}{l}\text { Outside the } \\
\text { house } n=2\end{array}$ & $\begin{array}{l}\text { Carcasses bin (S4) } \\
\mathbf{1 + / 1} \\
\text { Surroundings } \\
0+/ 1\end{array}$ & & & & & & \\
\hline Flock No $2^{*}$ & & & & & & ND & & & ND \\
\hline \multirow[t]{2}{*}{ Flock No $3^{*}$} & & & & 22/05/18 & $\begin{array}{l}\text { Inside the house } \\
n=7\end{array}$ & $\begin{array}{l}\text { Ventilation system } 2+/ \mathbf{4} \\
\text { Floor of the house } 0+/ 1 \\
\text { Changing room } 0+/ 1 \\
\text { Feed silo } 0+/ 1\end{array}$ & 13/06/18 & $\begin{array}{l}\text { Inside the } \\
\text { house } n=1\end{array}$ & Floor $0+/ 1$ \\
\hline & & & & & $\begin{array}{l}\text { Outside the house } \\
n=2\end{array}$ & $\begin{array}{l}\text { Surroundings } 0+/ 1 \\
\text { Carcasses bin } 0+/ 1\end{array}$ & & $\begin{array}{l}\text { Broilers } \\
n=20\end{array}$ & $\frac{\text { Cloacal swabs }}{4+/ 20 \text { (S6 and S7) }}$ \\
\hline \multirow[t]{2}{*}{ Flock No $4^{*}$} & & & & $9 / 07 / 18$ & $\begin{array}{l}\text { Inside the house } \\
n=2\end{array}$ & Ventilation system 0 + /2 & 6/08/18 & $\begin{array}{l}\text { Inside the } \\
\text { house } n=3\end{array}$ & $\begin{array}{l}\text { Ventilation system } \\
2+/ \mathbf{2} \\
\text { Floor } \mathbf{1}+/ \mathbf{1}\end{array}$ \\
\hline & & & & & $\begin{array}{l}\text { Material from the } \\
\text { hatchery } n=2\end{array}$ & Chick box bottom $2+/ 2$ & & $\begin{array}{l}\text { Broilers } \\
n=20\end{array}$ & $\begin{array}{l}\frac{\text { Cloacal swabs }}{\mathbf{1 7 + / 2 0}(\mathrm{S} 11 \text { to }} \\
\mathrm{S} 13)\end{array}$ \\
\hline \multirow[t]{4}{*}{ Flock No $5^{\star}$} & & & & $27 / 08 / 18$ & $\begin{array}{l}\text { Inside the house } \\
n=2\end{array}$ & Ventilation system $2+/ 2$ & 24/09/18 & $\begin{array}{l}\text { Broilers } \\
n=20\end{array}$ & $\begin{array}{l}\text { Cloacal swabs } \\
0+/ 20\end{array}$ \\
\hline & & & & & $\begin{array}{l}\text { Material from the } \\
\text { hatchery } \\
n=16\end{array}$ & $\begin{array}{l}\text { Chick box bottom } 0+/ 2 \\
\text { Article of the box bottom } \\
0+/ 10 \\
10 \text { chick boxes upon } \\
\text { arrival } 0+/ 2 \\
\text { Trolley and its wheels upor } \\
\mathbf{1 + / 2}(\mathrm{S} 8)\end{array}$ & val & & \\
\hline & & & & & $\begin{array}{l}\text { Chicks from the } \\
\text { hatchery } n=20\end{array}$ & $\begin{array}{l}\text { Cloacal swab on chicks } \\
0+/ 20\end{array}$ & & & \\
\hline & & & & & $\begin{array}{l}\text { Material returned to } \\
\text { the hatchery } n=4\end{array}$ & $\begin{array}{l}10 \text { chick boxes upon } \\
\text { departure } 0+/ 2 \\
\text { Trolleys and their wheels } \\
\text { upon departure } 0+/ 2\end{array}$ & & & \\
\hline
\end{tabular}

ND, no data.

*Number of positive samples/number of samples collected (positive samples are in bold).

Samples tested by MLVA are underlined and the sample code in Figure 2 is indicated in parentheses. 
cycle program: $95^{\circ} \mathrm{C}$ for $15 \mathrm{~min}, 35$ cycles of $30 \mathrm{~s}$ at $94^{\circ} \mathrm{C}$, of $1 \mathrm{~min}$ at $55^{\circ} \mathrm{C}$, of $1 \mathrm{~min}$ at $72^{\circ} \mathrm{C}$, and one final cycle at $72^{\circ} \mathrm{C}$ for $5 \mathrm{~min}$.

Multilocus variable-number of tandem-repeat analysis typing was performed on a T100 ThermalCycler (Bio-Rad, Marnesla-Coquette, France). PCR products were analyzed by capillary electrophoresis using a 2100 bioanalyzer system (Agilent, Les Ulis, France) to determine the number of repeats for each VNTR locus, deduced from each PCR product size. Fragment length and the corresponding number of repeat units was also checked by sequencing on a 3500 Series Genetic Analyzer (Applied Biosystems, Thermo Fischer Scientific, Illkirch-Graffenstaden, France).

The number of repeats obtained from each VNTR locus was imported into Bio-Numerics version 7.5 (Applied Math, SintMartens-Latem, Belgium) as character values. A dendrogram was calculated using the categorical coefficient and the UPGMA clustering algorithm to compare DNA extracts from samples tested in our study and available profiles from a previous study (Auricchio et al., 2019) or from other animal botulism outbreaks (Supplementary Table 2).

\section{RESULTS}

\section{Chronology of the Events in the Mixed Farm}

The chronology of the events is given in Table 1. Broiler Flock No. 1 was slaughtered on January 22, one week before the onset of the first clinical signs in cows. During their rearing period, an unusual event took place at 15 days of age: one side of the house collapsed due to a storm and caused the death of 120 broilers. The total mortality of this flock was 923 out of 20000 broilers (4.6\%). Otherwise, nothing unusual was reported regarding this flock nor for previous ones.

On January 26, poultry litter was removed from the house using a tractor bucket and manure was then stored in a field away from the farm ( $5 \mathrm{~km}$ from the farm). The same bucket was used later on the same day (after a quick rinse using a pressure cleaner with cold water) to prepare the cattle ration. Each ingredient of the cattle ration was taken one by one using the bucket and transferred to the mixing wagon to feed the cows later in the evening. Rape was taken first, then wrapped grass and meslin (all stored in Shed A as illustrated in Figure 1), then corn silage and finally brewery grains. Two days later, heifers were fed with the leftover dairy cattle ration. The day following the removal of poultry litter, Barn A was cleaned and disinfected as usual, with lime spread on the floor of the house and in the surroundings and a quaternary ammonium disinfectant sprayed (Spectragen ${ }^{\circledR}$, Synthèse Élevage, France) in the house.

On January 29, three days after the distribution of the ration, paralysis and the first mortalities were noticed in the dairy cows in Barn B and the diagnosis of botulism type D/C was confirmed the next day. Two days later, on January 31, the same clinical signs occurred in heifers in Barn C.
The same farm personnel and equipment used for poultry and cattle were employed for both production units. Noteworthily, the poultry carcass bin was located next to the changing room of the poultry house and the rendering truck must drive by the cattle barns to reach the poultry house to collect poultry carcasses from the bin (Figure 1).

At the second cattle site $10 \mathrm{~km}$ away, no clinical signs were observed. This site was handled by the same farm personnel, using different equipment.

\section{Detection of C. botulinum Type D/C on the Farm}

During the outbreak, 40 samples were collected at different times to investigate the source of contamination of cattle on the farm (Table 1). C. botulinum type D/C was detected in the five samples collected on February 5 from Flock No. 1 manure stored in a field since January 26 as well as three ingredients of the cattle ration (number of positive samples/number of samples tested, $3+/ 17$ ), i.e., meslin, wrapped grass, and rape. Wrapped grass was sampled at the same time as the samples for botulism diagnosis on January 30, whereas meslin and rape were sampled on February 5, several days after the initiation of botulism outbreak on the farm. Investigations conducted on February 23 revealed two positive samples in Barn B (liquid manure and swab of the floor), three positive samples in Shed A (swabs from the bucket, the mixing wagon and a rape tarpaulin) and three positive samples in the poultry house (two swabs from the ventilation system and one swab from the carcass bin). Given this detection of C. botulinum type D/C in the poultry house, extensive decontamination was implemented on March 19, with a strong cleaning agent (Decagen ${ }^{\circledR}$ detergent, Synthèse Élevage, France), with disinfection (Virugen ${ }^{\circledR}$, Synthèse Élevage, France) in the house and quicklime and caustic soda on the floor) and another disinfection using formaldehyde, with both procedures being carried out following the safety measures recommended when using such products.

After the outbreak, the 128 samples collected to monitor the contamination of broilers over time (Table 2) revealed the detection of C. botulinum type $\mathrm{D} / \mathrm{C}$ in the ventilation system of the poultry house $(8+/ 14)$ (after the extensive disinfection of the house: $2+/ 4$; upon chick delivery of the following flocks, $4+/ 8$; and at the end of the rearing period, $2+/ 2)$, contamination of some equipment coming from the hatchery $(3+/ 18)$ (2 swabs on chick box bottom and 1 swab of the egg transport trolleys and trolley wheels) and a continuous healthy carriage of broilers for several months detected in two consecutive flocks $(4+/ 20$ and $17+/ 20$ cloacal swabs in two flocks and 1 swab of the floor litter). Moreover, the carcass bin was still detected positive after the extensive disinfection of the house.

\section{Detection of C. botulinum Type D/C in the Poultry Hatchery}

Detection of C. botulinum at the hatchery is presented in Table 3. C. botulinum was detected in 6 out of the 58 samples: in the machine that cuts the article chick box, in the container of sludge washing water, on the loading platform, in the storage rooms 
TABLE 3 | Detection of C. botulinum type D/C at the hatchery delivering chicks on the farm $(n=58)$.

\begin{tabular}{|c|c|c|}
\hline & Sampling location & Detection of C. botulinum type D/C \\
\hline $\begin{array}{l}\text { Inside the hatchery } \\
{ }^{\star} n=41\end{array}$ & $\begin{array}{l}\text { Egg receiving room } \\
\text { Incubation room } \\
\text { Transfer (to hatcher) room } \\
\text { Hatcher room } \\
\text { Changing room } \\
\text { Chick sorting room } \\
\text { Chick departure room }\end{array}$ & $\begin{array}{l}0+/ 4 \\
0+/ 12 \\
0+/ 2 \\
0+/ 11 \\
0+/ 3 \\
1+/ 5 \text { Swab of the machine cutting the article box containing the chicks } \\
0+/ 4\end{array}$ \\
\hline $\begin{array}{l}\text { vOutside the } \\
\text { hatchery }{ }^{*} n=9\end{array}$ & $\begin{array}{l}\text { Trucks platforms } \\
\text { Waste containers } \\
\text { Central area } \\
\text { Breeder house surroundings }\end{array}$ & $\begin{array}{l}1+/ 3 \text { Swab of the loading platform } \\
1+/ 3 \text { Swab of the container of sludge washing water } \\
0+/ 1 \\
0+/ 2\end{array}$ \\
\hline Annex room ${ }^{\star} n=8$ & $\begin{array}{l}\text { Wash room (uncleaned egg trolleys) } \\
\text { Clean room (cleaned egg trolleys) } \\
\text { Egg holding (cooler) room }\end{array}$ & $\begin{array}{l}1+/ 3 \text { Swab of the room of the uncleaned egg trolleys (S9) } \\
2+/ 3 \text { Swab of the room of the cleaned egg trolleys } \\
\frac{\text { and swab of the trolley wheels }}{0+/ 2}(\mathrm{~S} 10)\end{array}$ \\
\hline
\end{tabular}

${ }^{*}$ Number of positive samples/number of samples collected. Samples tested by MLVA are underlined and the sample code in Figure 2 is indicated in parentheses. Samples detected positive are in bold.

of the uncleaned and cleaned egg trolleys, and on the wheels of the cleaned egg trolleys of hatching eggs. In addition, the epidemiological investigation revealed that the rendering truck entering the site to collect hatchery waste (silo of feathers and shells, breeder carcasses) passes hatchery vehicles or equipment (chick or egg delivery trucks, egg trolleys wheeled outside to be stored in annex rooms).

\section{MLVA Analysis}

Thirteen samples positive for C. botulinum type D/C were selected among the 291 samples analyzed in our study. Samples were selected so as to obtain an overview of the different investigated areas included in our study and to be as representative as possible of the encountered samples and situations, and finally to compare and evaluate the relatedness of strains detected in the different positive samples. Unfortunately, MLVA results obtained with samples initially detected positive for type $\mathrm{D} / \mathrm{C}$ with a late $\mathrm{Ct}$ (above 35) using real-time PCR were not interpretable (such as for example the swab on the bucket).

Samples selected for MLVA analysis are indicated in Tables 1-3 and detailed number of detected repeats for each VNTR locus in Supplementary Table 3.

A dendrogram was generated based on the VNTR repeat unit profiles (Figure 2). Two different profiles were detected among the selected samples. Three cloacal swabs collected in Flock No. 4 presented a profile different from the other samples (76.8\% of similarities between the two groups). These results show that at least two different strains were detected during these investigations with the detection in Flock No. 4 broilers with a profile different from the one detected during the cattle outbreak. However, no differences could be detected between the other investigated samples (Flock No. 1 manure, ruminal contents from a dead cow, cloacal swabs collected in Flock No. 3, samples from the hatchery), demonstrating the presence of the same strain in all these samples.

\section{DISCUSSION}

An overview of the detection of C. botulinum type D/C on the farm (poultry and cattle barns) and in the hatchery as well as the reference of samples that were compared using MLVA is provided in Figure 3. This figure also presents the most likely scenario of the contamination pathways suggested by our investigations.

\section{Identification of the Source of Cattle Contamination Through Epidemiological Investigations}

Poultry manure has been reported to be a major source for cattle botulism outbreaks (Payne et al., 2011; Ramírez-Romero et al., 2014; Relun et al., 2017; Souillard et al., 2017). Poultry manure is also incriminated in this study, based on the chronology of the outbreak events, and our results showing positive samples (particularly the poultry manure samples) as well as MLVA profiles similar between the manure and the cows that suffered from botulism (Group 1, Figure 2). The positive manure samples from poultry Flock No. $1(5+/ 5)$ as well as the detection of C. botulinum in three samples collected within the poultry house (2 swabs of the ventilation system and 1 swab of the carcass bin) strongly suggest that $C$. botulinum type $\mathrm{D} / \mathrm{C}$ was present in the poultry house when Flock No. 1 was present.

The tractor bucket used to remove broiler litter from the poultry house and then shortly after used to prepare the cattle ration was also positive for $C$. botulinum type $\mathrm{D} / \mathrm{C}$ and may have transferred the contamination from poultry manure to the ration ingredients $(3+/ 17)$ and to the mixing wagon, which was positive as well. The three ingredients of the ration first taken with the bucket were all detected positive (rape, wrapped grass, and meslin). The MLVA results of the meslin moreover showed the same profile as Flock No. 1 manure and ruminal contents from a dead cow. The succession of these events seems therefore to have resulted in the contamination of dairy cattle fed with this ration, thereby initiating the outbreak. Ration leftovers were then 

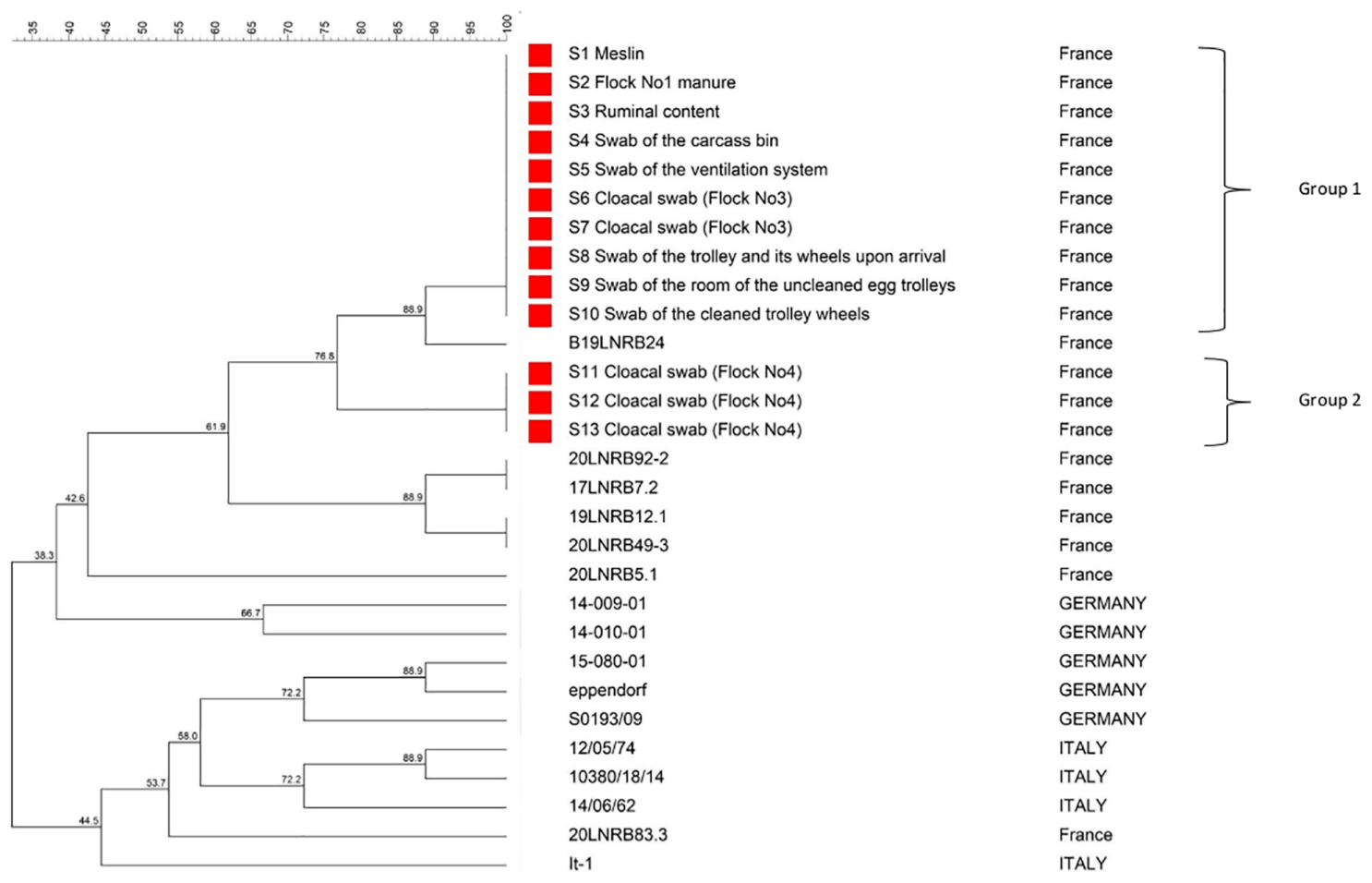

FIGURE 2 | Multilocus variable-number tandem repeat analysis (MLVA) dendrogram of 13 samples collected in this study and positive for C. botulinum type D/C (in red) and 16 other strains of $C$. botulinum type D/C (typed in other studies) constructed using the UPGMA method, implemented in BioNumerics. The name and code of samples from our study and names of strains from previous studies and their respective country are shown on the right. Samples S1-S13 were separated in 2 groups based on MLVA similarities.

distributed to heifers resulting in the onset of the disease in these animals as well. It is noteworthy that these samples were collected after the outbreak, except for the wrapped grass, therefore crosscontamination secondary to the outbreak cannot be completely ruled out. However, regarding the timing of the events and the analysis results, this seems unlikely. MLVA results also strongly support this scenario, the same profile being detected in Flock No. 1 manure, ruminal contents from a cow, ration ingredients as well as in samples collected in the poultry house after the Flock No. 1 rearing period.

An unusual event that occurred during the Flock No. 1 growth period may explain the manure contamination. The sudden death of 120 broilers due to the collapse of one side of the house during the rearing period may have increased the risk of carcasses being left in the litter despite daily carcass removal by the farmer. Carcasses as a decaying organic matter harboring high amounts of protein substrates and anaerobic conditions is known to support the growth of C. botulinum and BoNT production (Anniballi et al., 2013). Any stress factor in broilers can disturb the balance of the intestinal ecosystem (Tsiouris, 2016); therefore this event may have induced stress in broilers thereby providing favorable conditions for C. botulinum growth by modifying intestinal balance. The speed of the onset of clinical signs, 2 days after the distribution of contaminated ration, may be compatible with intoxication of the cattle by ingestion of preformed BoNTs. This hypothesis was supported by the detection of vegetative cells only, and not spores in the ruminal contents of two cows sampled at the beginning of the outbreak. Ruminal contents were only positive when analyzed using TPGY and not F-CMM, which includes a heat treatment.

In addition to this scenario, several biosecurity failures were also highlighted during the investigation. First, the storage conditions of the cattle ration ingredients were not appropriate, because they were stored uncovered, exposing them to potential contamination by wild birds or rodents. Providing safe, highquality, and properly stored feed to animals is one of the key measures to minimize the risk of botulism (Anniballi et al., 2013). Rodents may be a reservoir of a variety of pathogens, in particular C. botulinum (Popoff, 1995; Popp et al., 2012; Skarin et al., 2013; Souillard et al., 2014). Moreover, the location of the rendering container (carcass bin), testing positive on two occasions, next to the poultry house can be a source of poultry contamination. Its location also obliges the rendering truck to drive alongside the cattle barns. Given the risk generated by carcasses in regard to botulism and the ability of spores to persist in the environment (Popoff, 1995), the management of the carcasses on a farm is a major critical point for the prevention of the disease. Third, equipment is also shared between the dairy and poultry production units, which can result in crosscontamination between the units. Finally, close proximity of poultry and dairy cows (less than $10 \mathrm{~m}$ between both barns with transversal ventilation in the poultry house) may also be a source of C. botulinum dissemination via dust and wind. Dust inside the ventilation system in the poultry house is frequently 


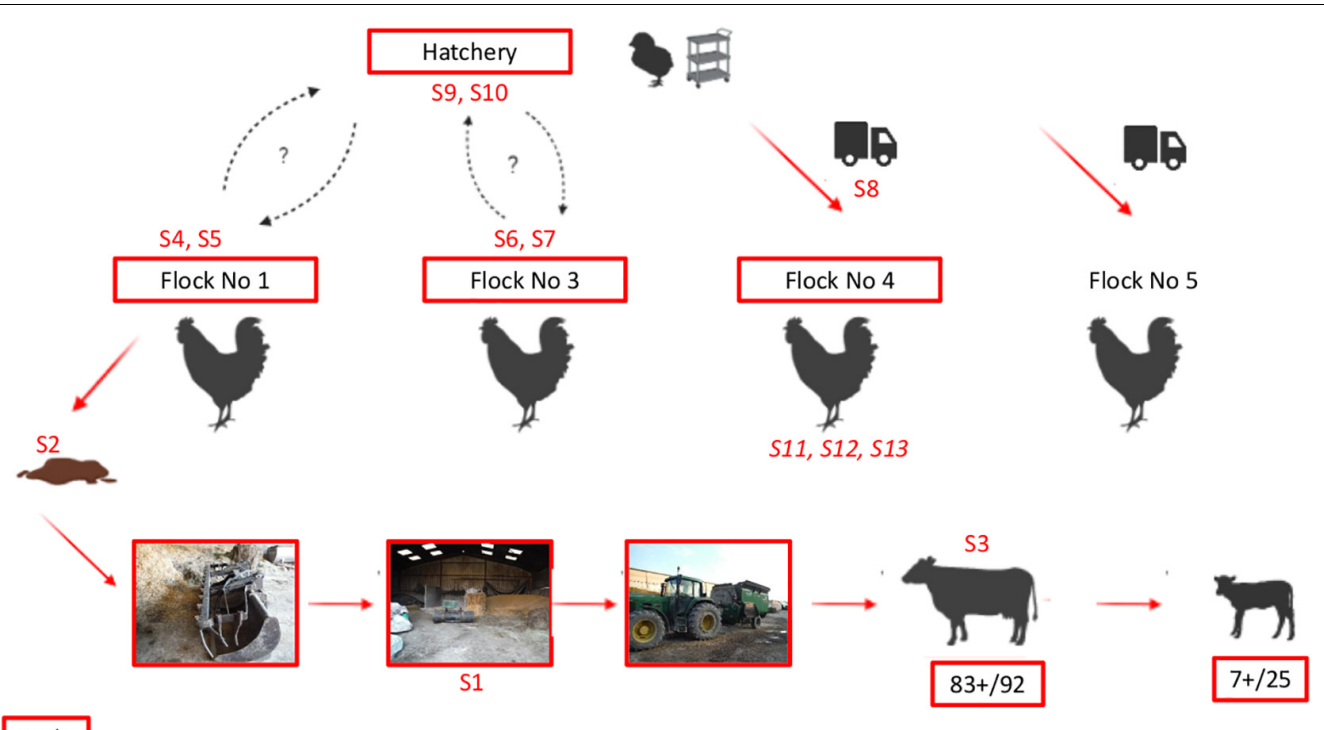

FIGURE 3 | Diagram summarizing the likely relationships between the broilers, cattle, and hatchery based on investigations and results obtained in this study. Samples collected during the study and positive for C. botulinum type D/C are shown in red. References of samples tested using MLVA (Figure 2) are mentioned in the diagram. Note that samples S11-S13 are shown in italics in contrast to the other samples (S1-S10), because they showed a different MLVA profile (Figure 2).

" + D/C": sample positive for bont D/C using PCR are surrounded in Red. Detailed results of samples collected and analyzed in our study are given in Table $\mathbf{1}$ (initial investigations during cattle botulism outbreak), Table $\mathbf{2}$ (monitoring of successive broiler flocks), and Table $\mathbf{3}$ (investigations in the hatchery that delivers chicks to the farm).

contaminated after a botulism outbreak (Souillard et al., 2014). Windborne transmission of spore- or BoNT- contaminated material has also been suggested (Hogg et al., 2008).

Since this outbreak, specific measures have been implemented to prevent recurrence of the disease: animals are vaccinated yearly, feed storage area has been reorganized, each component being now separated and protected; the bucket used to load feed in the mixing-wagon is now dedicated only to this activity, the tractor used for poultry manure is no longer used for cows feed; boots and clothes used for poultry and bovines by the farmer are now separated and dedicated to one activity. No new case has been reported since then.

\section{Monitoring of Broilers Contamination Over Time}

Few data are available regarding healthy carriage of C. botulinum in poultry and it remains a current issue to better understand the onset of animal botulism (Rasetti-Escargueil et al., 2019). Our monitoring of broilers on this farm using cloacal swabs revealed continuous healthy carriage of C. botulinum in successive broiler flocks over several months. After the first detection of C. botulinum in the poultry house in January, the following broiler flocks remained healthy carriers of C. botulinum at least until August as demonstrated by positive cloacal swabs detected at the end of the rearing period for two flocks.

At least two scenarios can be considered to explain this persistent contamination of broilers over time on the farm. First, our monitoring showed persistence of C. botulinum type $\mathrm{D} / \mathrm{C}$ in the house, particularly in the ventilation system $(8+/ 14)$, despite the disinfection operations conducted between each flock. This detection is likely due to the high resistance of spores in the environment that can survive for several years (Notermans et al., 1981; Wobeser et al., 1987), particularly in the critical areas of the poultry house that are difficult to disinfect, such as the ventilation systems, as reported previously (Souillard et al., 2014, 2016). Consequently, this environmental persistence of C. botulinum in the poultry house is a source of recontamination and may have resulted in healthy carriage in successive broiler flocks. A second scenario that may explain C. botulinum carriage in broilers for several months is the re-introduction of $C$. botulinum via chick delivery, suggested by the detection of C. botulinum on equipment from the hatchery. Two swabs collected on chick box bottoms for Flock No. 4 and one swab collected on trolleys and their wheels for Flock No. 5 were already positive for C. botulinum type $\mathrm{D} / \mathrm{C}$ upon their arrival on the farm, before any contact with the farm. The same MLVA profile was detected for sample S8 (see Figure 2) as previous samples collected in the farm (Table 2 and Figure 3). Considering these findings, the question of a potential contamination of the hatchery thus arose and investigations were implemented in the hatchery delivering chicks to the farm to better explore this hypothesis.

\section{Evaluation of Hatchery Contamination}

Clostridium botulinum type D/C was detected in 6 of the 58 samples collected in the hatchery: on materials (machine cutting the article box containing the chicks and wheels of trolleys transporting the hatching eggs), in the annex room (room where trolleys of hatching eggs are stored) and on 
outside surroundings (in the container of sludge washing water and on the platform where hatching eggs are unloaded). Contaminated areas were either located outside or in areas that are recognized as difficult to clean and disinfect. One sample positive for C. botulinum type D/C tested using MLVA showed the same profile (Group 1) as samples collected during the outbreak, demonstrating that the same strain was detected in both places.

During the hatchery visit and based on detection of C. botulinum type $\mathrm{D} / \mathrm{C}$ in some samples, several risk factors were identified. First, similar vehicle routes were highlighted, in which rendering trucks and hatchery vehicles or equipment, for example, pass each other. Failures in cleaning and disinfection operations were also pointed out, as illustrated by the detection of C. botulinum type D/C on the system used to cut article boxes during chick delivery or in the room used to store cleaned trolleys or on wheels of cleaned trolleys.

In poultry breeding, the hatchery occupies a central position by being in daily contact with breeder farms to collect eggs and with broiler farms to deliver chicks. Hatcheries can serve as a reservoir and source of pathogenic microorganisms and via the movement of vehicles (delivery trucks), people or equipment (trays, trolleys, and chick boxes, etc.) can facilitate the dissemination of microorganisms (McMullin, 2009; Osman et al., 2018). Consequently, the contamination detected in our study in the hatchery can be also explained by this permanent, exchange of potentially healthy carriers of $C$. botulinum between the hatchery and broiler farms. It was not possible to identify the initial source of contamination, i.e., hatchery or poultry farms, here, because the hatchery was only taken into account after the botulism case investigation had begun.

Despite the hygiene and biosecurity procedures in the hatcheries, infectious agents can contaminate hatcheries by being transported on or within eggs, on hatchery personnel, on trolleys and trays, or as airborne contaminants (Wales and Davies, 2020). A wide range of microorganisms, such as Salmonella, E. coli, Pseudomonas, Staphylococci, Mycoplasma, or Aspergillus, can be detected in hatcheries and disseminated to chicks and subsequently to farms (Qureshi, 2002; McMullin, 2009). To the best of our knowledge, there is currently no data available regarding the contamination of hatcheries by $C$. botulinum. The risks of hatchery contamination arise from the hygiene of hatching eggs, the multiple exchanges between farms, and also the management of the hatchery, involving vehicles, people and equipment all along the process from the arrival of the hatching eggs to the delivery of chicks to customer farms (Qureshi, 2002; McMullin, 2009). In our study, C. botulinum type D/C was not detected in any of the samples collected in the incubation $(n=12)$ and hatching rooms $(n=11)$. Moreover, no asymptomatic carriage was detected in chicks delivered on the farm using cloacal swabs on Flock No. 5. The hatching process is considered as the most risky step for microbial dissemination (McMullin, 2009; Kim and Kim, 2010). This does not seem to be the case here based on detection results. No vertical transmission of C. botulinum from breeders to chicks was demonstrated here or in previous studies. The exact role of hatcheries in the epidemiology of animal botulism requires further investigation.

\section{MLVA as a Useful Tool for Epidemiological Investigations}

Genotyping methods such as pulsed-field gel electrophoresis (PFGE) and amplified fragment length polymorphism (AFLP) have been successfully used in the context of animal botulism outbreaks for tracking strains (Myllykoski et al., 2009; Skarin et al., 2015). However such approaches require isolation of pure strains, thus limiting the number of samples that can be analyzed. Despite improvements regarding C. botulinum group III isolation (Le Gratiet et al., 2020), it is still timeconsuming and phages encoding BoNT are easily lost. MLVA has been available for C. botulinum group I and II for many years (Fillo et al., 2011; Umeda et al., 2013; Anniballi et al., 2016). It has been recently developed for C. botulinum group III subtyping (Auricchio et al., 2019). MLVA presents a major advantage because it does not require the isolation of the strain and can be directly used on DNA extracted from the initial samples (Kahlisch et al., 2010; Chen et al., 2011; Pereyre et al., 2012; Pailhoriès et al., 2015). Our study demonstrates the usefulness of the MLVA approach as a subtyping tool intended for tracing and tracking C. botulinum group III, in particular for investigations during animal botulism outbreaks.

In our study, profiles of samples encoded S1 to S10 were shown to be identical (Group 1). Three cloacal swabs collected on broilers from Flock No. 4 presented a different profile from the other samples collected during the study $(76.8 \%$ similarity between Groups 1 and 2). The origin of this second profile was not explained here. Unfortunately, MLVA results from samples collected at the beginning of the Flock No. 4 rearing period were not interpretable (DNA amount was too low in these samples as shown by a late Ct obtained for these samples). Therefore, it was not possible to determine if this contamination could be linked to the hatchery or not. Samples from the hatchery (samples S8, S9, S10) were indeed all part of Group 1.

\section{CONCLUSION}

This study demonstrates that broilers can be healthy carriers of C. botulinum type $\mathrm{D} / \mathrm{C}$ that can lead to cattle contamination and in the initiation of a botulism outbreak. This also shows that this contamination can last several months, spanning successive flocks. This study also shows that the environment of hatcheries can be contaminated by $C$. botulinum and may become a source of introduction of C. botulinum in poultry farms via chick delivery. As illustrated by a massive cattle botulism outbreak due to cross-contamination between poultry and cows, this study highlights the major importance of the implementation of appropriate biosecurity measures in mixed farms to avoid cross-contamination between the production units involving equipment (specific material or disinfection), vehicles (separate travel routes) and personnel (shoes and clothes in shower room). Further investigations are now required to evaluate $C$. botulinum contamination occurrence and level in hatcheries so as to better understand their potential role in the epidemiology of botulism. 


\section{DATA AVAILABILITY STATEMENT}

The original contributions presented in the study are included in the article/Supplementary Material, further inquiries can be directed to the corresponding author.

\section{ETHICS STATEMENT}

Samples were collected by veterinarians for diagnostic purposes on dead animals (death due to the botulism outbreak). Cloacal swabs were collected on broilers in the farm by veterinarians for official analyses. This article presents non-experimental clinical veterinary studies. Animals on farms were treated in accordance with the European and French regulation on farmed animal protection. Samples were collected in accordance with Regulation EC/1099/2009 and Directive 2010/63/EU. Written informed consent was obtained from the owners for the participation of their animals in this study.

\section{AUTHOR CONTRIBUTIONS}

CL, RS, SL, DG, and MC designed the study. CL, TP, SR, SM, and LM analyzed the samples for detection of C. botulinum. RS and $\mathrm{CL}$ analyzed the data and drafted the manuscript. DG, RS, and LB collected the epidemiological data and samples on field. TL and FA were in charge of the MLVA analysis. SL, FA, and MC provided their expertise feedback. All authors reviewed the draft and contributed significantly to the final manuscript.

\section{REFERENCES}

Anniballi, F., Fillo, S., Giordani, F., Auricchio, B., Tehran, D. A., Di Stefano, E., et al. (2016). Multiple-locus variable number of tandem repeat analysis as a tool for molecular epidemiology of botulism: the Italian experience. Infect. Genet. Evol. 46, 28-32. doi: 10.1016/j.meegid.2016.10.014

Anniballi, F., Fiore, A., Löfström, C., Skarin, H., Auricchio, B., Woudstra, C., et al. (2013). Management of animal botulism outbreaks: from clinical suspicion to practical countermeasures to prevent or minimize outbreaks. Biosec. Bioterrorism 11, S191-S199. doi: 10.1089/bsp.2012.0089

Auricchio, B., Scalfaro, C., Vicenza, T., Bano, L., Bilei, S., Chemaly, M., et al. (2019). Multilocus Variable-Number of Tandem-Repeat Analysis as a tool for Clostridium Botulinum Group III Subtyping ANIBOTNET Workshop Botulism, Paris, 28-29 march 2019.

Bano, L., Drigo, I., Tonon, E., Pascoletti, S., Puiatti, C., Anniballi, F., et al. (2017). Identification and characterization of Clostridium botulinum group III field strains by matrix-assisted laser desorption-ionization time-of-flight mass spectrometry (MALDI-TOF MS). Anaerobe 48, 126-134. doi: 10.1016/j. anaerobe.2017.08.004

Chen, S., Li, J., Saleh-Lakha, S., Allen, V., and Odumeru, J. (2011). Multiple-locus variable number of tandem repeat analysis (MLVA) of Listeria monocytogenes directly in food samples. Int. J. Food Microbiol. 148, 8-14. doi: 10.1016/j. ijfoodmicro.2011.04.014

Fillo, S., Giordani, F., Anniballi, F., Gorgao, O., Ramisse, V., Vergnaud, G., et al. (2011). Clostridium botulinum group I strain genotyping by 15-locus multilocus variable-number tandem-repeat analysis. J. Clin. Microbiol. 49, 4252-4263. doi: 10.1128/JCM.05396-11

Hogg, R., Livesey, C., and Payne, J. (2008). Diagnosis and implications of botulism. In Practice 30, 392-397. doi: 10.1136/inpract.30.7.392

Kahlisch, L., Henne, K., Draheim, J., Brettar, I., and Höfle, M. G. (2010). High-resolution in situ genotyping of Legionella pneumophila populations

\section{FUNDING}

This work was funded by the French Agency for Food, Environmental and Occupational Health \& Safety (ANSES), the Côtes d'Armor Departmental Council, and the ANIBOTNET project (ANIHWA call). TL is the recipient of a Ph.D. grant from ANSES and the Bretagne Regional Council, and the recipient of a short stay grant funded by the MedVetNet Association for a training period regarding the MLVA method at the ISS laboratory in Italy under Fabrizio Anniballi's supervision.

\section{ACKNOWLEDGMENTS}

The authors would like to thank the farmers and veterinarians for their participation in the study; Concetta Scalfaro (ISS) for her help in MLVA analysis; and Valérie Rose (ANSES, Ploufragan Laboratory) and François-Xavier Briand (ANSES, Ploufragan Laboratory) for their help and expertise in the sequencing PCR products for MLVA analysis. Figure 3 was created with BioRender.com.

\section{SUPPLEMENTARY MATERIAL}

The Supplementary Material for this article can be found online at: https://www.frontiersin.org/articles/10.3389/fmicb. 2021.679377/full\#supplementary-material

in drinking water by multiple-locus variable-number tandem-repeat analysis using environmental DNA. Appl. Environ. Microbiol. 76, 6186-6195. doi: 10. 1128/aem.00416-10

Kim, J. H., and Kim, K. S. (2010). Hatchery hygiene evaluation by microbiological examination of hatchery samples. Poultry Sci. 89, 1389-1398. doi: 10.3382/ps. 2010-00661

Le Gratiet, T., Poezevara, T., Rouxel, S., Houard, E., Mazuet, C., Chemaly, M., et al. (2020). Development of an innovative and quick method for the isolation of Clostridium botulinum strains involved in avian botulism outbreaks. Toxins (Basel) 12:42. doi: 10.3390/toxins12010042

Le Maréchal, C. L., Hulin, O., Macé, S., Chuzeville, C., Rouxel, S., Poëzevara, T., et al. (2019). A case report of a botulism outbreak in beef cattle due to the contamination of wheat by a roaming cat carcass: from the suspicion to the management of the outbreak. Animals 9:1025. doi: 10.3390/ani9121025

McMullin, P. F. (2009). Hygiene and microbiological control in hatcheries. Avian Biol. Res. 2, 93-97. doi: 10.3184/175815509X431885

Myllykoski, J., Lindström, M., Keto-Timonen, R., Söderholm, H., Jakala, J., Kallio, H., et al. (2009). Type C bovine botulism outbreak due to carcass contaminated non-acidified silage. Epidemiol. Infect. 137, 284-293. doi: 10. 1017/S0950268808000939

Notermans, S., Dufrenne, J., and Oosterom, J. (1981). Persistence of Clostridium botulinum type B on a cattle farm after an outbreak of botulism. Appl. Environ. Microbiol. 41, 179-183. doi: 10.1128/aem.41.1.179-183.1981

Osman, K. M., Kappell, A. D., Elhadidy, M., Elmougy, F., El-Ghany, W. A. A., Orabi, A., et al. (2018). Poultry hatcheries as potential reservoirs for antimicrobial-resistant Escherichia coli: a risk to public health and food safety. Sci. Rep. 8:5859. doi: 10.1038/s41598-018-23962-7

Pailhoriès, H., Buzelé, R., Picardeau, M., Robert, S., Mercier, E., Mereghetti, L., et al. (2015). Molecular characterization of Leptospira sp by multilocus variable number tandem repeat analysis (MLVA) from clinical samples: a case report. Int. J. Infect. Dis. 37, 119-121. doi: 10.1016/j.ijid.2015.06.026 
Payne, J. H., Hogg, R. A., Otter, A., Roest, H. I., and Livesey, C. T. (2011). Emergence of suspected type D botulism in ruminants in England and Wales (2001 to 2009), associated with exposure to broiler litter. Vet. Rec. 168:640. doi: $10.1136 /$ vr.d1846

Peck, M. W., Smith, T. J., Anniballi, F., Austin, J. W., Bano, L., Bradshaw, M., et al. (2017). Historical perspectives and guidelines for botulinum neurotoxin subtype nomenclature. Toxins 9:38. doi: 10.3390/toxins9010038

Pereyre, S., Charron, A., Hidalgo-Grass, C., Touati, A., Moses, A. E., Nir-Paz, R., et al. (2012). The spread of Mycoplasma pneumoniae is polyclonal in both an endemic setting in France and in an epidemic setting in Israel. PLoS One 7:e38585. doi: 10.1371/journal.pone.0038585

Popoff, M. (1989). Revue sur l'épidémiologie du botulisme bovin en France et analyse de sa relation avec les élevages de volailles. Rev. Sci. Tech. Off. Int. Epiz. 8, 129-145. doi: 10.20506/rst.8.1.404

Popoff, M. R. (1995). "Ecology of neurotoxigenic strains of clostridia," in Clostridial Neurotoxins. Current Topics in Microbiology and Immunology, ed. C. Montecucco (Berlin: Springer-Verlag), 1-29. doi: 10.1007/978-3-642-85 173-5_1

Popoff, M. R., and Argente, G. (1996). Le botulisme animal est-il une menace pour l'homme ? Bull. l'Académie Vétérinaire France 69, 373-382. doi: 10.4267/2042/ 63881

Popp, C., Hauck, R., Gad, W., and Hafez, H. M. (2012). Type C botulism in a commercial Turkey farm: a case report. Avian Dis. 56, 760-763. doi: 10.1637/ 10274-061212-Case.1

Qureshi, A. (2002). Hatchery sanitization and chick mortality. World Poultry 18, 24-25.

Ramírez-Romero, R., Ramírez-Hernández, C., García-Márquez, L. J., MacedoBarragán, R. J., Martínez-Burnes, J., and López-Mayagoitia, A. (2014). Bovine diseases causing neurological signs and death in Mexican feedlots. Trop. Anim Health Prod. 46, 823-829. doi: 10.1007/s11250-014-0572-y

Rasetti-Escargueil, C., Lemichez, E., and Popoff, M. R. (2019). Public health risk associated with botulism as foodborne zoonoses. Toxins (Basel) 12:17. doi: 10.3390/toxins 12010017

Rasetti-Escargueil, C., Lemichez, E., and Popoff, M. R. (2020). Human botulism in France, 1875-2016. Toxins (Basel) 12:338. doi: 10.3390/toxins1205 0338

Relun, A., Dorso, L., Douart, A., Chartier, C., Guatteo, R., Mazuet, C., et al. (2017). A large outbreak of bovine botulism possibly linked to a massive contamination of grass silage by type D/C Clostridium botulinum spores on a farm with dairy and poultry operations. Epidemiol. Infect. 145, 3477-3485. doi: $10.1017 / \mathrm{s} 0950268817002382$

Senturk, S., and Cihan, H. (2007). Outbreak of botulism in a dairy herd in Turkey. Ir. Vet. J. 60, 481-484. doi: 10.1186/2046-0481-60-8-481

Skarin, H., Lindgren, Y., and Jansson, D. S. (2015). Investigations into an outbreak of botulism caused by Clostridium botulinum Type C/D in laying hens. Avian Dis. 59, 335-340. doi: 10.1637/10861-051214-Case
Skarin, H., Tevell Åberg, A., Woudstra, C., Hansen, T., Löfström, C., Koene, M., et al. (2013). The workshop on animal botulism in Europe. Biosec. Bioterrorism 11, S183-S190. doi: 10.1089/bsp.2012.0076

Souillard, R., Le Marechal, C., Ballan, V., Mahe, F., Chemaly, M., and Le Bouquin, S. (2017). A bovine botulism outbreak associated with a suspected crosscontamination from a poultry farm. Vet. Microbiol. 208, 212-216. doi: 10.1016/ j.vetmic.2017.07.022

Souillard, R., Le Marechal, C., Ballan, V., Rouxel, S., Leon, D., Balaine, L., et al. (2016). Investigation of a type $\mathrm{C} / \mathrm{D}$ botulism outbreak in free-range laying hens in France. Avian Pathol. 46, 195-201. doi: 10.1080/03079457.2016. 1240355

Souillard, R., Woudstra, C., Le Marechal, C., Dia, M., Bayon-Auboyer, M. H., Chemaly, M., et al. (2014). Investigation of Clostridium botulinum in commercial poultry farms in France between 2011 and 2013. Avian Pathol. 43, 458-464. doi: 10.1080/03079457.2014.957644

Tsiouris, V. (2016). Poultry management: a useful tool for the control of necrotic enteritis in poultry. Avian Pathol. 45, 323-325. doi: 10.1080/03079457.2016. 1154502

Umeda, K., Wada, T., Kohda, T., and Kozaki, S. (2013). Multi-locus variable number tandem repeat analysis for Clostridium botulinum type B isolates in Japan: comparison with other isolates and genotyping methods. Infect. Genet. Evol. 16, 298-304. doi: 10.1016/j.meegid.2013.02.022

Wales, A., and Davies, R. (2020). Review of hatchery transmission of bacteria with focus on Salmonella, chick pathogens and antimicrobial resistance. World's Poultry Sci. J. 76, 517-536. doi: 10.1080/00439339.2020.1789 533

Wobeser, G., Marsden, S., and Macfarlane, R. J. (1987). Occurrence of toxigenic Clostridium botulinum type $\mathrm{C}$ in the soil of wetlands in Saskatchewan. J. Wildlife Dis. 23, 67-76. doi: 10.7589/0090-3558-23.1.67

Woudstra, C., Skarin, H., Anniballi, F., Fenicia, L., Bano, L., Drigo, I., et al. (2012). Neurotoxin gene profiling of Clostridium botulinum types C and D native to different countries within Europe. Appl. Environ. Microbiol. 78, 3120-3127.

Conflict of Interest: The authors declare that the research was conducted in the absence of any commercial or financial relationships that could be construed as a potential conflict of interest.

Copyright (c) 2021 Souillard, Grosjean, Le Gratiet, Poezevara, Rouxel, Balaine, Macé, Martin, Anniballi, Chemaly, Le Bouquin and Le Maréchal. This is an open-access article distributed under the terms of the Creative Commons Attribution License (CC BY). The use, distribution or reproduction in other forums is permitted, provided the original author(s) and the copyright owner(s) are credited and that the original publication in this journal is cited, in accordance with accepted academic practice. No use, distribution or reproduction is permitted which does not comply with these terms. 